\title{
COMPOSITES IN INFRASTRUCTURE
}

Modern composite materials were originally created and utilized basically in the aircraft and space industry. These materials show a superb combination of strength and weight and are very convenient in use. However, their initial cost was so high that their application to other branches of national economy seemed practically unreal. But the situation gradually changes - the cost of composites reduces, and while the possibilities of their use in construction sharply grow. Concrete itself is a brittle material but when concrete structures are reinforced with composites, their strength and safety increase considerably.

During the last years, the journal "Mechanics of Composite Materials" have been receiving an increased amount of articles dedicated to the application of fibrous composites in construction. Taking into account the specific interests of our readers, it is desirable that the studies on composites in building and other spheres of national economy be published separately. Therefore, the Editorial Board decided to dedicate a separate issue of the journal to composites in construction, namely to the strengthening of concrete structures and the creation of hybrid designs.

Editorial Board

Translated from Mekhanika Kompozitnykh Materialov, Vol. 50, No. 4, pp. 571-572, July-August, 2014. 